\title{
THE IMPACT OF PHYSICAL ACTIVITY IN THE: 'KEEP YOUR BODY STRAIGHT' PROGRAM ON THE SELECTED FEATURES OF BODY POSTURE IN FRONTAL AND TRANSVERSE PLANES IN CHILDREN AGED 7-9 YEARS
}

\author{
WPŁYW WYSIŁKU FIZYCZNEGO STOSOWANEGO W RAMACH PROGRAMU \\ „TRZYMAJ SIĘ PROSTO” NA WYBRANE CECHY POSTAWY CIAŁA \\ W PŁASZCZYŹNIE CZOŁOWEJ I POPRZECZNEJ \\ DZIECI W WIEKU 7-9 LAT
}

\author{
${ }^{1}$ Social Academy of Sciences \\ ${ }^{2}$ Kazimierz Wielki University, Institute of Physical Culture \\ ${ }^{3}$ Chair and Department of Biochemistry CM UMK
}

\begin{abstract}
S u m mary
The main causes of majority of health problems in children and teenagers include incorrect health behaviors and adverse effects of socioeconomic environment.

The purpose of this study is to determine the impact of physical activity in the 'Keep your body straight' program on incorrect body postures in children aged 7-9 years.

Material and methods. 1864 children in classes I-III of primary schools were included in the study. The assessment of posture was conducted in six half-year long editions under the 3-year program using a photogrammetric method and concerned the same group of pupils. Children participated in corrective activities as a part of the 'Keep your body straight' program.

The above mentioned program positively influenced the torso bending angle to the left and less to the right. A similar effect was observed in the size of the maximum inclination of the atlas vertebra to the left, in the spinous process and to a lesser extent, in the inclination to the right. In addition, a

positive effect was noticed in pelvic rotation in the transverse plane. Other features like the angle of shoulder line, the asymmetry of waist triangle height and width, the asymmetry of shoulders, shoulder blades and pelvis in frontal plane did not reveal any significant differences in the process.

Conclusions. 1. Corrective activities of the 'Keep your body straight' program combined with education of parents are moderately effective means in the correction process of wrong postures in frontal and transverse planes in children of both sexes aged 7-9 years. 2. Physical activity applied within the program significantly influenced the vertical orientation of torso and maximum deviation of the spinous process of vertebrae in the frontal plane and the value of pelvic rotation in the transverse plane. 3 . The effectiveness of the program can be enhanced by an individual approach to every 'advanced incorrect' posture in a child, which could not be achieved under the program due to insufficient funds of the school.
\end{abstract}

Głównymi przyczynami większości zaburzeń w stanie zdrowia dzieci i młodzieży są nieprawidłowe zachowania i niekorzystne czynniki środowiska socjoekonomicznego.
Określenie wpływu stosowanego wysiłku fizycznego w ramach programu korekcyjnego „Trzymaj się prosto” na błędy postawy ciała 7-9 letnich dzieci. Materiał i metodyka. Badaniami objęto 1864 dzieci klas I-III. Oceny postawy ciała 
dokonano w 6 półrocznych edycjach 3-letniego programu, w tej samej grupie uczniów, metodą fotogrametryczną. Dzieci uczestniczyły w programowych zajęciach korekcyjnych „Trzymaj się prosto”.

Zastosowany program wpływa pozytywnie na: kąt zgięcia tułowia w lewo, mniej na kąt zgięcia w prawo. Podobny wpływ zaobserwowano w wielkości maksymalnego odchylenia kręgu szczytowego w lewo, w przebiegu linii wyrostków kolczystych kręgosłupa, mniej w odchyleniu w prawo. Wpłynął także korzystnie na wielkość skręcenia miednicy w płaszczyźnie poprzecznej. Wielkości pozostałych cech: kąta linii barków, asymetrii wysokości i szerokości trójkątów taliowych, asymetrii barków i łopatek oraz miednicy w płaszczyźnie czołowej nie wykazywały znaczących różnic w przebiegu.
Wnioski. 1. Zastosowane ćwiczenia korekcyjne w ramach programu „Trzymaj się prosto” połączone z edukacją rodziców jest umiarkowanie skutecznym środkiem w procesie naprawczym błędów postawy ciała w płaszczyźnie czołowej i poprzecznej dzieci obojga płci w wieku od 7 do 9 lat. 2. Zastosowany wysiłek fizyczny wpłyną znacząco na wertykalność tułowia i wielkość maksymalnego odchylenia wyrostka kolczystego kręgu w płaszczyźnie czołowej oraz wielkość skręcenia miednicy w płaszczyźnie poprzecznej. 3. Efektywność programu można zwielokrotnić, indywidualnym podejściem do każdej „zaawansowanej błędliwej” postawy dziecka, czego nie udało się zrealizować ze względu ograniczone środki finansowe szkoły.

Key words: body posture, frontal plane, transverse plane, program "Keep going straight", children

Stowa kluczowe: postawa ciała, płaszczyzna czołowa, płaszczyzna poprzeczna, program „Trzymaj się prosto”, dzieci

\section{INTRODUCTION}

In recent years increasing attention has been paid to the issues of health and health care of a student of Polish schools. Health promoting programs have been developed as reflected in numerous publications $[1,2$, 3 , 4]. The main causes of most health problems in children and teenagers from towns and rural areas include incorrect health behaviors and adverse effects of their socioeconomic environment (mainly home environment). It should be emphasized that in addition to essential environmental factors, the human condition is also affected by genetic determinants [5]. According to the studies, $77 \%$ of teenagers spend more than 2 hours a day watching television, whereas $44 \%$ of boys and $31 \%$ of girls as much as 4 hours on a daily basis [3]. The research carried out in 1978-1980 among pupils in classes I-IV of primary schools in the southeast macro region showed better physical condition of children from rural areas and small towns in comparison to children from big cities, while the level of somatic development of children from cities was higher when compared to their rural counterparts [6]. Different environmental characteristics can be clearly observed in development of Polish children. This particularly refers to strength, speed and agility, which can be observed particularly among girls. As it results from surveys, about one third of 25 European schools of higher education which responded to the survey sent to them, conduct corrective activities, that is, in Belgium: University of Leuven, the Netherlands: universities in Eindhoven and Nijmegen, Germany: universities in Hamburg, Essen, Hannover, Sweden: Uppsala University and University of Gothenburg,
Hungary: University of Goddollo. Polish universities did not respond to the survey, nor did the British and French ones [7].

Body posture asymmetries in frontal and transverse planes comprise a complex problem. Posture asymmetry helps distribute body weight evenly on load-bearing surfaces of the motor system; however, lack of asymmetry may lead to overload syndromes [8]. That could be treated as one of home environmental impacts. Still, the prevalence of these syndromes makes one wonder about efficiency of physical activity during school corrective exercises under the program and PE classes. Own scientific studies have shown [9] that these activities do not meet the expected requirements. In consequence, basic functions of physical education including stimulation, adaptation, compensation, correction and such targets as maintaining the natural motility of children and youth, improving physical activity, developing talents in physical activity and managing the development of movement features are not fulfilled. Krawański [10] reports that body posture stimulants consist of: development and efficiency of skeletal muscles, maintaining the optimal volume of joint movement and preserving the upright position reflex.

The purpose of the study is to determine the impact of physical activity in the 'Keep your body straight' program on incorrect body postures in children aged 79 years. 


\section{MATERIAL, METHODS AND SUBJECT}

The research program was implemented in 20072010. The first edition included first class pupils from 21 randomly chosen primary schools from the Warmińsko - Mazurskie region. The study group was regarded as homogenous in terms of their place of residence as dividing children into groups from cities and rural areas would be improper and this characteristic would never determine the homogenous character of the group. From among all children qualified by a school doctor, the measurements covered those who had been diagnosed with improper body postures using Postorumeter M. Eventually the study included 1864 children ( 977 girls and 887 boys). Test results of girls from class I -322 , II - 383, III 272 were eligible for the purpose of analysis and in case of boys: $316,325,246$, respectively. The average body weight of girls aged 7 was $26.42 \mathrm{~kg}$ and their average height was $121.0 \mathrm{~cm}$. The 8-year old girls' average weight was $26.42 \mathrm{~kg}$ and height: $128.28 \mathrm{~cm}$ and for 9-year old girls these were $30.14 \mathrm{~kg}$ and 132.87 $\mathrm{cm}$, respectively. As far as boys are concerned, the average weight at the age of 7 was $23.21 \mathrm{~kg}$ and height: $127.93 \mathrm{~cm}$. For age 8, these were $28.0 \mathrm{~kg}$ and $130.23 \mathrm{~cm}$, respectively; and for age 9: $31.34 \mathrm{~kg}$ and $134.47 \mathrm{~cm}$, see Figure 1. The children participated in the corrective activities into which a pro-health 'Keep your body straight' program was implemented [11].
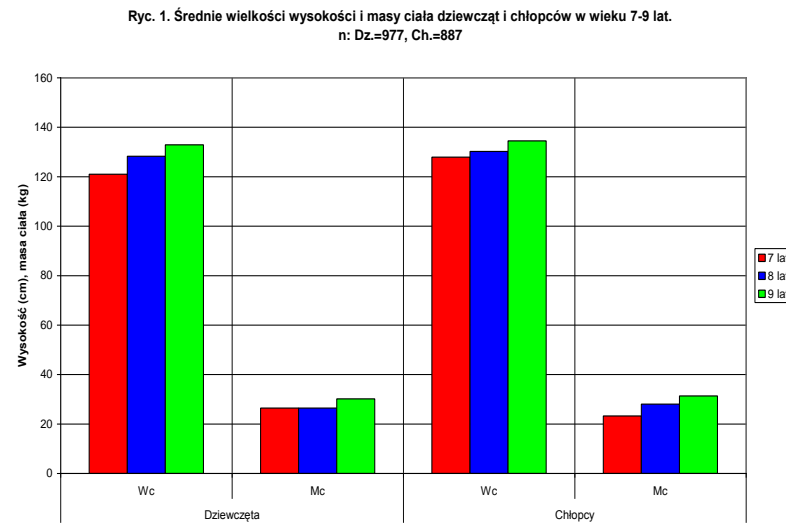

The methodology used for the study used multiplane symmetries and asymmetries of the habitual spinal-pelvic posture. In order to analyze the values of selected parameters a device for computer posture assessment with mora projection was applied. The study methods and technique were in line with the established principles [12]. The results obtained in the form of spatial and graphic images ensured a numerical description of the features investigated. 20 selected features concerning body posture in frontal and transverse planes were subjected to statistical analysis, Table 1.
Table 1. The list of measured postural features in frontal and transverse planes

\begin{tabular}{|c|c|c|c|c|}
\hline 1 & KNT - & degrees & $\begin{array}{l}\text { Torso lateral } \\
\text { deflection angle }\end{array}$ & $\begin{array}{l}\text { The left-sided deflection } \\
\text { of the line C7-S1 from } \\
\text { the vertical. }\end{array}$ \\
\hline 2 & KNT & degrees & & $\begin{array}{l}\text { The right-sided } \\
\text { deflection of the line C7- } \\
\text { S1 from the vertical }\end{array}$ \\
\hline 3 & KLB & $\mathrm{Mm}$ & \begin{tabular}{|l}
$\begin{array}{l}\text { Shoulders line } \\
\text { angle }\end{array}$ \\
\end{tabular} & \\
\hline 4 & LBW - & $\mathrm{Mm}$ & \begin{tabular}{|l|l|}
$\begin{array}{l}\text { Right shoulder } \\
\text { higher }\end{array}$ \\
\end{tabular} & \multirow{2}{*}{$\begin{array}{l}\text { Distance measured } \\
\text { vertically between the } \\
\text { horizontal lines crossing } \\
\text { points B2 and B4 }\end{array}$} \\
\hline 5 & LBW & $\mathrm{mm}$ & $\begin{array}{l}\text { Left shoulder } \\
\text { higher }\end{array}$ & \\
\hline 6 & LEW & $\mathrm{mm}$ & $\begin{array}{l}\text { Left shoulder } \\
\text { blade higher }\end{array}$ & \multirow{2}{*}{$\begin{array}{l}\text { Distance measured } \\
\text { vertically between the } \\
\text { horizontal lines crossing } \\
\text { points Ł1 } 1 \mathrm{kp}\end{array}$} \\
\hline 7 & LŁW - & $\mathrm{mm}$ & $\begin{array}{l}\text { Right shoulder } \\
\text { blade higher }\end{array}$ & \\
\hline 8 & LŁB & $\mathrm{mm}$ & \begin{tabular}{|lr} 
Lower & angle of \\
left & shoulder \\
blade & more \\
distant &
\end{tabular} & \multirow{2}{*}{$\begin{array}{l}\text { Difference in the distance } \\
\text { between the lower angles } \\
\text { of shoulder blades and } \\
\text { the spinous process } \\
\text { measured horizontally on } \\
\text { the straight lines passing } \\
\text { through points } Ł l \text { and } Ł p\end{array}$} \\
\hline 9 & PŁB & $\mathrm{mm}$ & \begin{tabular}{|lr} 
Lower & angle of \\
right & shoulder \\
blade & more \\
distant & \\
\end{tabular} & \\
\hline 10 & LTTw & $\mathrm{mm}$ & \begin{tabular}{|l|l|} 
Left waist \\
triangle higher
\end{tabular} & \multirow{2}{*}{$\begin{array}{l}\text { Difference in the distance } \\
\text { measured vertically } \\
\text { between points T1 - T2 } \\
\text { and T3 -T4. } \\
\text { PLTT = LTT - PTT }\end{array}$} \\
\hline 11 & PTT w & $\mathrm{mm}$ & $\begin{array}{l}\text { Right waist } \\
\text { triangle higher }\end{array}$ & \\
\hline 12 & LTT s & $\mathrm{mm}$ & $\begin{array}{|lr|}\text { Left waist } & \text { waiangle broader } \\
\text { trial }\end{array}$ & \multirow{2}{*}{$\begin{array}{l}\text { Difference in the distance } \\
\text { measured horizontally } \\
\text { between the straight lines } \\
\text { passing through points } \\
\text { T1 - T2 and T3 - T4 }\end{array}$} \\
\hline 13 & PTT s & $\mathrm{mm}$ & $\begin{array}{l}\text { Right waist } \\
\text { triangle broader }\end{array}$ & \\
\hline 14 & KNM & degrees & $\begin{array}{l}\text { Pelvic } \\
\text { inclination, } \\
\text { right iliac ala } \\
\text { higher } \\
\end{array}$ & \multirow{2}{*}{$\begin{array}{l}\text { The angle between the } \\
\text { vertical line and the } \\
\text { straight line passing } \\
\text { through points } \\
\text { M1 and Mp }\end{array}$} \\
\hline 15 & $\begin{array}{l}\mathrm{KNM} \\
-\end{array}$ & degrees & $\begin{array}{l}\text { Pelvic } \\
\text { inclination, left } \\
\text { iliac ala higher }\end{array}$ & \\
\hline 16 & $\begin{array}{l}\text { UK } \\
(\text { dex })\end{array}$ & $\mathrm{mm}$ & $\begin{array}{l}\text { Maximum } \\
\text { deviation of } \\
\text { spinous process } \\
\text { to the right }\end{array}$ & \multirow{2}{*}{$\begin{array}{l}\text { Maximum deviation of } \\
\text { spinous process from the } \\
\text { vertical going from S1. } \\
\text { The distance is measured } \\
\text { in the horizontal axis. }\end{array}$} \\
\hline 17 & $\begin{array}{l}\text { UK- } \\
(\sin )\end{array}$ & $\mathrm{mm}$ & \begin{tabular}{|l} 
Maximum \\
deviation of \\
spinous process \\
to the left \\
\end{tabular} & \\
\hline 18 & $\mathrm{NK}$ & & $\begin{array}{lr}\text { Number } & \text { of } \\
\text { vertebra } & \text { with } \\
\text { maximum } & \text { left } \\
\text { or right } & \text { sided } \\
\text { deviation } & \end{array}$ & $\begin{array}{l}\text { Number of vertebra with } \\
\text { maximum left or right } \\
\text { sided deviation in the } \\
\text { asymmetric line of } \\
\text { spinous process, counting } \\
\text { the first neck vertebra } \\
\left(C_{1}\right) \text { as } 1 \text {. }\end{array}$ \\
\hline \multicolumn{5}{|c|}{ Transverse Plane } \\
\hline 19 & KSM & degrees & $\begin{array}{l}\text { Pelvic rotation } \\
\text { to the right }\end{array}$ & $\begin{array}{l}\text { Angle between the line } \\
\text { passing through point M1 } \\
\text { and being perpendicular } \\
\text { to the axis of the camera } \\
\text { and the straight passing } \\
\text { through Ml and MP at } \\
\text { the same time }\end{array}$ \\
\hline 20 & KSM - & degrees & $\begin{array}{l}\text { Pelvic rotation } \\
\text { to the left }\end{array}$ & $\begin{array}{l}\text { Angle between the line } \\
\text { passing through point Mp } \\
\text { and being perpendicular } \\
\text { to the axis of the camera } \\
\text { and the straight passing } \\
\text { through Ml and MP at } \\
\text { the same time }\end{array}$ \\
\hline
\end{tabular}

Source: own study 


\section{RESULTS}

The results of measurements from all six half-year long editions under the 3-year research program were subjected to statistical analysis. Empirical data were quantitative features. They were presented in the description as the arithmetical mean and standard deviation. The set of features revealed a normal distribution, that is why proper parametric tests were used for the purpose of further calculations. Required statistical calculations were performed using the program Statistica StatSoft, Inc. (2005). STATISTICA (data analysis software system), version 6.3 www. statsoft. lic. no. AXAP311B316618AR.

Table 2. Average values of selected postural features in frontal and transverse planes in the group of girls $(n=977)$

\begin{tabular}{|l|c|c|c|c|c|c|c|c|c|c|c|c|}
\hline \multirow{2}{*}{ Feature } & \multicolumn{10}{|c|}{ Subsequent measurements and standard deviation } \\
\cline { 2 - 15 } & 1 & SD & 2 & SD & 3 & SD & 4 & SD & 5 & SD & 6 & SD \\
\hline KNT p & 7.22 & 3.7 & 5.11 & 3.21 & 3.1 & 3.41 & 2.1 & 3.39 & 2.1 & 3.5 & 2 & 3.32 \\
\hline KNT 1 & 2.21 & 2.01 & 2.3 & 2.11 & 1.35 & 2.04 & 1.3 & 2.01 & 1.2 & 2.11 & 1.1 & 2.11 \\
\hline KNMwp & 8.9 & 3.61 & 8 & 3.87 & 8 & 3.41 & 7.9 & 3.27 & 7.8 & 3.51 & 7.9 & 3.64 \\
\hline KNMwl & 1.5 & 1.96 & 1.9 & 2.01 & 1.5 & 2.11 & 1.6 & 2.05 & 1.8 & 1.36 & 1.6 & 1.97 \\
\hline KSMwl & 13.32 & 4.91 & 13.23 & 5.01 & 12.34 & 13.54 & 11.3 & 12.96 & 11.21 & 4.71 & 10.19 & 4.94 \\
\hline KSMwp & 2.32 & 1.89 & 2.3 & 1.76 & 2.29 & 2.14 & 2.13 & 2.11 & 2.11 & 1.79 & 2.1 & 1.76 \\
\hline KLB & 4.5 & 3.21 & 4.5 & 3.11 & 4.1 & 3.19 & 4.2 & 3.15 & 4.2 & 3.61 & 4.3 & 3.23 \\
\hline LBW & 18.45 & 5.21 & 18.78 & 5.11 & 18.47 & 5.08 & 18.67 & 5.06 & 18.56 & 5.31 & 18.12 & 5.24 \\
\hline PBW & 10.45 & 3.72 & 10.78 & 3.64 & 10.45 & 3.52 & 11.67 & 3.51 & 11.56 & 3.62 & 10.87 & 3.75 \\
\hline LŁW & 14.05 & 4.76 & 14275 & 4.65 & 13.67 & 4.35 & 13.51 & 4.34 & 13.52 & 4.46 & 13.49 & 4.78 \\
\hline PŁW & 3.87 & 3.21 & 3.97 & 3.11 & 3.87 & 3.04 & 3.94 & 3.03 & 4 & 3.31 & 3.98 & 3.23 \\
\hline LŁB & 16.8 & 5.41 & 15.89 & 5.21 & 15.67 & 5.11 & 15.59 & 5.09 & 16 & 5.81 & 15.98 & 5.45 \\
\hline PŁB & 8.5 & 3.65 & 8.68 & 3.55 & 8.73 & 3.57 & 8.68 & 3.68 & 8.58 & 3.25 & 8.46 & 3.66 \\
\hline LTTw & 24.23 & 7.61 & 24.12 & 6.98 & 23.98 & 6.73 & 24.02 & 6.78 & 23.87 & 7.51 & 23.82 & 7.62 \\
\hline PTTw & 47.37 & 11.34 & 46.34 & 10.76 & 47.12 & 10.57 & 47.32 & 10.71 & 47.12 & 11.24 & 47.02 & 11.14 \\
\hline LTTs & 21.34 & 9.76 & 21.25 & 9.71 & 21.3 & 9.57 & 21.24 & 10.02 & 21.25 & 9.66 & 21.14 & 9.12 \\
\hline PTTs & 45.7 & 8.76 & 45.56 & 8.12 & 45.46 & 8.17 & 44.98 & 9.21 & 45.12 & 8.26 & 45 & 8.16 \\
\hline UK wl & 15.4 & 7.65 & 15.32 & 7.55 & 14.89 & 7.51 & 13.87 & 7.51 & 12.21 & 7.35 & 11.21 & 7.35 \\
\hline UK wp & 6.36 & 3.21 & 6.35 & 3.04 & 6.29 & 3.01 & 6.3 & 3.11 & 6.29 & 3.41 & 6.28 & 3.41 \\
\hline NK & 8 & 6.54 & 8 & 5.89 & 8 & 5.76 & 8 & 5.68 & 8 & 6.44 & 8 & 6.24 \\
\hline Source:
\end{tabular}

Source: own study

The results revealed that physical activity in the 'Keep your body straight' program had similar impact on male and female children. A positive correction was noticed in: torso left-sided deflection angle (KNT-) and, to a lesser extent, torso right-sided deflection angle (KNT-), Figure 2.

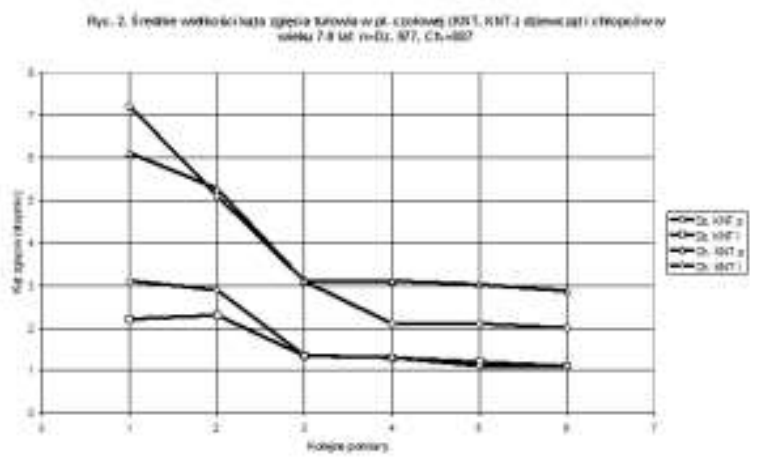

Similar influence was observed in the maxim the size of the maximum inclination of the atlas vertebra to the left, in the spinous process (UK-) and, to a lesser degree, to the right, Figure 7. In addition, physical activity under the correction program positively influenced the value of pelvic rotation in the transverse plane to the left and right, Figure 3 . The values of other features including shoulders line angle, the asymmetry of waist triangle height and width, the asymmetry of shoulders, shoulder blades and pelvis did not reveal any significant differences in the process, Figure 4, 5, 6 , 7. It should be assumed that (despite a strictly observed research procedure) the results obtained from measurement of these features were within the limits of individual variability. Besides, the researcher provided some information to parents of the children with pelvic asymmetry in the frontal plane highlighting the possibility of correcting the difference in limb length of every shoe after an orthopedic consultation.

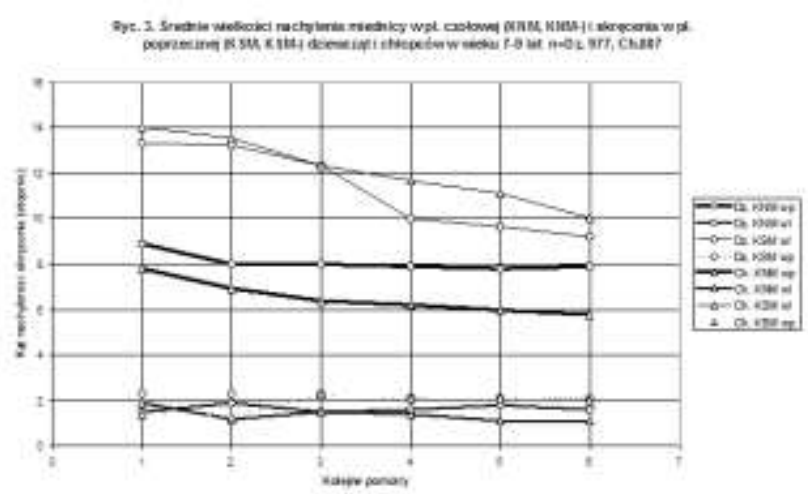


Table 3. Average values of selected postural features in frontal and transverse planes in the group of boys $(n=887)$

\begin{tabular}{|l|c|c|c|c|c|c|c|c|c|c|c|c|c|}
\hline \multirow{2}{*}{ Feature } & \multicolumn{10}{|c|}{ Subsequent measurements and standard deviation } \\
\cline { 2 - 16 } & 1 & SD & 2 & SD & 3 & SD & 4 & SD & 5 & SD & 6 & SD \\
\hline KNT p & 6.12 & 3.6 & 5.28 & 3.41 & 3.1 & 3.21 & 3.11 & 3.49 & 3.02 & 3.51 & $2 . .87$ & 3.32 \\
\hline KNT 1 & 3.11 & 2.11 & 2.89 & 2.11 & 1.35 & 2.64 & 1.31 & 2.41 & 1.11 & 2.13 & 1.11 & 2.41 \\
\hline KNMwp & 7.81 & 3.51 & 6.94 & 3.67 & 6.39 & 3.31 & 6.21 & 3.57 & 5.98 & 3.55 & 5.79 & 3.54 \\
\hline KNMwl & 1.9 & 1.86 & 1.18 & 2.51 & 1.5 & 2.21 & 1.4 & 2.65 & 1.11 & 1.37 & 1.1 & 1.77 \\
\hline KSMwl & 11.32 & 4.61 & 10.02 & 5.71 & 12.34 & 13.84 & 12.13 & 12.86 & 11.11 & 4.72 & 10.04 & 4.84 \\
\hline KSMwp & 1.42 & 1.39 & 1.31 & 1.86 & 2.29 & 2.15 & 2.1 & 2.14 & 2.12 & 1.54 & 2.01 & 1.66 \\
\hline KLB & 3.5 & 3.21 & 3.11 & 3.41 & 4.1 & 3.25 & 3.91 & 3.12 & 3.82 & 3.64 & 3.73 & 3.63 \\
\hline LBW & 15.21 & 5.51 & 14.98 & 5.21 & 18.47 & 5.14 & 18.17 & 5.32 & 18.02 & 5.38 & 17.82 & 5.44 \\
\hline PBW & 8.36 & 3.82 & 8.28 & 3.84 & 10.45 & 3.43 & 10.37 & 3.54 & 10.16 & 3.69 & 9.97 & 3.65 \\
\hline LEW & 12.13 & 5.56 & 12.15 & 4.25 & 13.67 & 4.36 & 13.11 & 4.38 & 13.12 & 4.49 & 12.92 & 4.48 \\
\hline PŁW & 2.12 & 4.31 & 2.97 & 3.31 & 3.87 & 3.51 & 3.24 & 3.41 & 3.21 & 3.34 & 3.8 & 3.73 \\
\hline LLB & 13.51 & 4.51 & 13.19 & 5.81 & 15.67 & 5.28 & 15.49 & 5.48 & 14.96 & 5.88 & 14.38 & 5.95 \\
\hline PŁB & 6.95 & 4.15 & 6.68 & 3.95 & 8.73 & 3.49 & 8.68 & 3.66 & 8.28 & 3.28 & 8.01 & 3.36 \\
\hline LTTw & 22.11 & 6.51 & 22.12 & 6.68 & 23.98 & 6.21 & 23.02 & 6.73 & 23.27 & 7.57 & 22.94 & 7.52 \\
\hline PTTw & 4129 & 10.84 & 41.34 & 9.23 & 47.12 & 10.1 & 46.92 & 10.21 & 46.22 & 11.52 & 46.02 & 11.44 \\
\hline LTTs & 19.28 & 9.78 & 19.15 & 8.72 & 21.3 & 9.39 & 21.14 & 10.12 & 20.55 & 9.43 & 20.14 & 9.28 \\
\hline PTTs & 41.28 & 9.16 & 40.16 & 7.92 & 45.46 & 8.48 & 44.18 & 9.26 & 43.82 & 8.29 & 43.03 & 8.36 \\
\hline UK wl & 13.42 & 6.55 & 13.12 & 7.65 & 14.89 & 7.32 & 13.12 & 7.41 & 12.1 & 7.37 & 10.21 & 7.43 \\
\hline UK wp & 6.16 & 4.11 & 6.11 & 3.14 & 6.29 & 3.28 & 6.01 & 3.81 & 5.19 & 3.48 & 5.04 & 3.27 \\
\hline NK & 7 & 6.14 & 7 & 5.29 & 7 & 5.77 & 7 & 5.38 & 7 & 6.49 & 7 & 6.23 \\
\hline
\end{tabular}

Source: own study
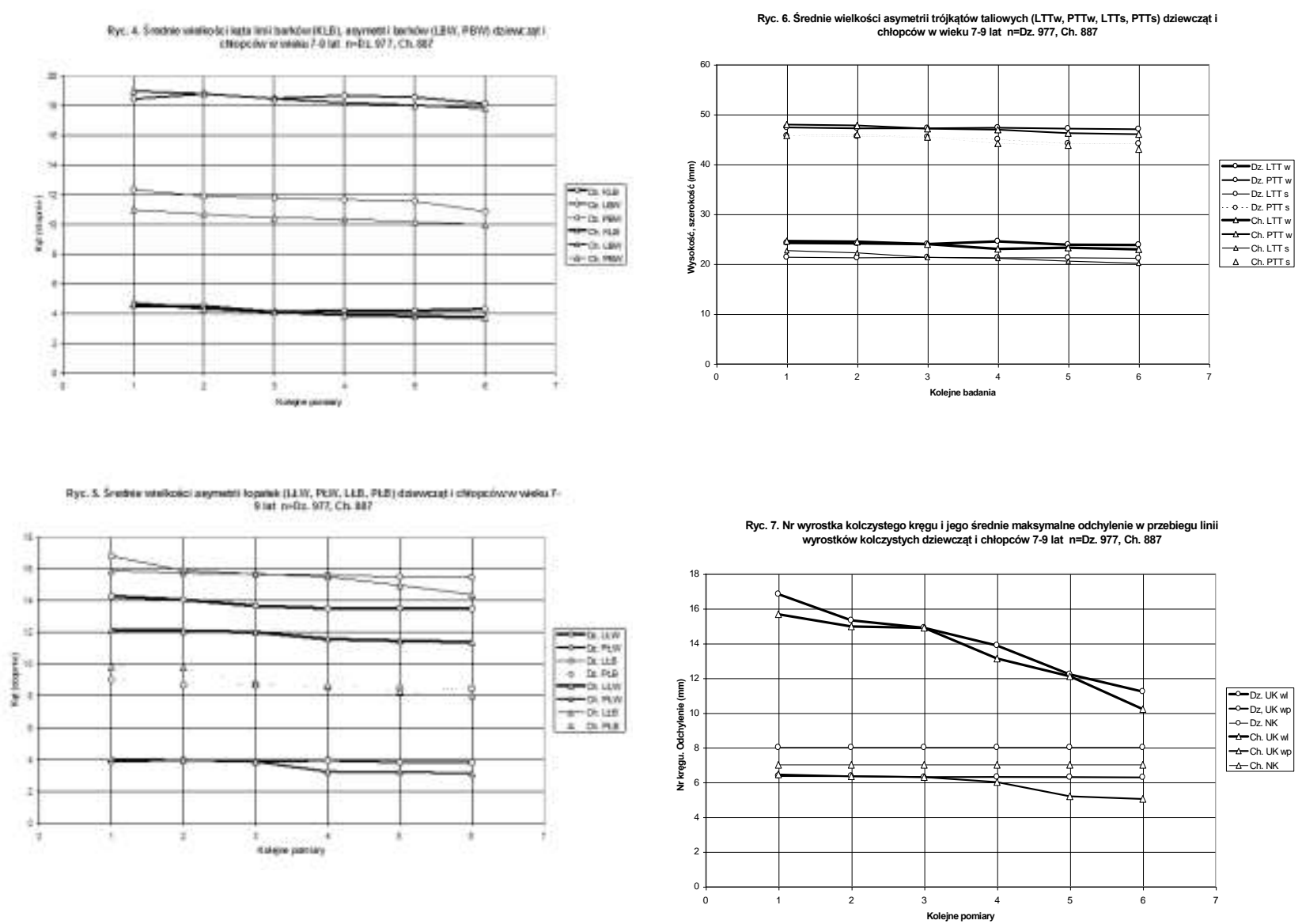


\section{DISCOURSE}

Weber [13, 14] believes that physical activity focused on postural correction cannot impact on structural changes or bone growth. The central European model appears to be more logical as opposed to the American system in terms of using corrective exercises at schools. However, the whole point of these exercises is that they should be effective. It has been found that the time preceding the first menstrual period in girls and mutation in boys is a critical moment in preventive therapy $[15,16,17]$. Hence, corrective exercises to straighten posture, performed during that period, reduce a thoracic kyphosis, increase a lumbar lordosis and, in consequence, lead to increased rotation and subsequent progression of postural curvature with scoliotic changes. Malawski [18] and Karski [19] emphasize that improper exercises are used in order to strengthen long dorsal muscles running along the scoliosis chord and causing an auxotonic pressure on the curvature which can strengthen hypertonic tension of soft tissue affected by scoliosis. Torell [20] reported that early therapy using focused exercises preceded by early diagnosis leads to reduced occurrence of scoliosis above 40 degrees by $63 \%$.

\section{CONCLUSIONS}

1. Corrective activities of the 'Keep your body straight' program combined with education of parents are moderately effective means in the correction process of wrong postures in frontal and transverse planes in children of both sexes aged 7-9 years.

2. Physical activity applied within the program significantly influenced the vertical orientation of torso and maximum deviation of the spinous process of vertebrae in the frontal plane and the size of pelvic rotation in the transverse plane.

3. The effectiveness of the program can be enhanced by an individual approach to every 'advanced defective' posture in a child, which could not be achieved under the program due to insufficient funds of the school.

\section{REFERENCES}

1. Błażejewski Z., 1991, Health education, important and urgent tasks, New school, No. 3.
2. Gniewkowski W., 1988, Health promotion, School life, No. 5.

3. Woynarowska B., 1996, How to promote health, Careeducational problems, No. 6.

4. Łubkowska W., Troszczyński J., 2011, Verification of physical activity as a criterion for assessing the body posture of girls and boys aged 7-15 years. Scientific Journals of the University of Szczecin, Essays of the Institute of Physical Culture No. 631(27), page 27-40.

5. Łubkowska W., Tarnowski M., 2012, „Too little exercise never helps - too much is not good?" - comparison of opinion criterion. Physical activity of people of various ages, No. 16, page 91-102.

6. Report of the Experts' Committee, 1990, Health of children and youth in education, New school, No. 4.

7. General Board of AZS, 2004, European debate about "Physical education of students at European universities" within II Academic Council of Physical Culture in Szczecin.

8. Łubkowska W., Iwanowski W., Zalewski T., 2002, Evaluation of spinal mobility symmetry in girls aged 7 15 years. Polish physiotherapy, No., 2 (2), page 154-163.

9. Mrozkowiak M., 2004, Efficiency of physical activity under postural corrective exercises in children aged 7-9 years from selected schools in the Warmińsko-Mazurskie region, [w] Pęczkowski [red.], Polish educational system after the reform in 1999, II International Scientific Conference: Education of the 21st century, Piła

10. Krawański A., 1993, Process of body posture formation from a systemic perspective, [w] Spinal dysfunctions diagnosis and therapy [red.] Nowotny J., AWF Katowice.

11. Mrozkowiak M, 2004, Concept of school correction Club "Keep your body straight", [w] Pęczkowski [red.], Polish educational system after the reform in $1999,2^{\text {nd }}$ International Scientific Conference: Education of the $21^{\text {st }}$ century, Piła.

12. Mrozkowiak M., Strzecha M., Mora projection as a contemporary diagnostic tool for assessing body posture, Anthropomotoric aspects, 2012, Kraków, v. 22, No. 60, page 33-49.

13. Weber M., 1985, Entwicklung und Effektivitat der krankengymnastischen Behandlung der Skoliose. Krankengymnastik, 37, 11, 743-748.

14. Weber M., Hirsch PAGE, 1986, Krankengymnastik bei idiopathischer Skoliose. Gustav Fischer Verlag, Stuttgart.

15. Dobosiewicz K., 1997, Lateral idiopatic curvatures of the spine, Śląska Akademia Medyczna, Katowice.

16. Kotwicki T., et al 2002, Impact of exercises on idiopatic scoliosis - proposal of multienvironmental research, Rehabilitation progress, No. 16, Supplement 3.

17. Kotwicki T. et al, 2001, Pathomechanics of idiopathic scoliosis in three planes and the consequences for the choice of corrective exercises in children with scoliosis, Rehabilitation progress, No. 15(3), page 47-48.

18. Malawski PAGE, 1994, Own principles of treating low degree scoliosis in the light of modern outlook at scoliosis ethiology and pathogenesis, Musculosceletal surgery and Polish orthopedics, LIX, No. 3.

19. Karski T., 1996, Contractures and growth disorders 
within the region of hip and pelvis as the cause of developing "idiopathic scoliosis", Biomechanical discourse., Musculosceletal surgery and Polish orthopedics, Volume LXI, No. 1.

20. Torell G. et all., 1981, The Changing pattern of scoliosis treatment due to effective screening. Journal of Bone and Joints Surgery, 63A, 337.
Address for correspondence:

e-mail: magmar54@interia.pl

Received: 9.05.2016

Accepted for publication: 10.06.2016 